\title{
TEOLOGIA PRAKTYCZZNA
}

UNIWERSYTBT IM: ADAMA MICKIBWICZA WYDZLAE TEOLOCICQNY

TOM 3,2002

\section{ANDRZEJ CZAJA \\ Podstawowe elementy eklezjologii communio}

"Communig" należy do tych wielkich i upraywilejowanych tematów Soboru, które promieniuja niemal z każdej stronicy soborowych dokumentow. Z tym pojęciem wiaże się nowa świadonośc Kosciola, a mianowicie postrzeganie siebie jako wspólnoty zamjerzonej przez Boga, zakorzenionej w Bogu i prowadzącej do jedności z Bogiem.

Wyratna promocję stlezjologil communio obserwuje síc od momentu opublikowania Relatio finalis II Nadzwyczajnego Zgromadzenja Generalnego Synodu Biskupów w 1985 rokk (por. RF II,C)". Synod zareagowat na zbyt socjologiczne i polityczne rozumienie faworyzowanej po Soborze idei ludu Bożego. Kongregacja Nauki Wiary przedstawia ramy katolickiego rozamienia komunii Kościola w liscie Communionis notio (CN). W nowym katechizmie elementy eklezjologii communto zostały wplecio-

${ }^{1}$ Zdariem Ojcou Synodu, eklezjologia communto jest ideą centralną i podstawową w dokumentach Soboru - por. RK 1], C, 1; CL 19. Do roku 1985 pozostaje jednak nie mal njezauważona. Co prawda, B. Mondin przedstawiając aktkalne eklezjologie, postrzega obok eklezjologi teandryczej (min. Ch, Joumet), kerygmatyconej (K. Barth, R. Bultmann), ekumenicznej ( $\mathbf{Q}$, Congar, O. Cullmann, G. Florowsy), sakramentalnej (O. Semmelroth, K. Rahner, E. Schillebeeckx, 1. Ratringer, H.U. von Balthasar), pneunatologicanej (H. Küng, H. Mūhlen, J. Moltmann, P. Tílich, N. A Janasjew) i historycznej (H. de Lubac, P. Farente, L. Bouyer), takce wspolnotowa (E. Brumer, J. Hamer) - zob. B. Mondin Le nuove ecclesialogie. Un imagine atuale della Chiesa. Roma 1980; J. Hamer : $L$ ' Eglise egf une communion, Paris 1962. Jednak katolickie rozumienie communio Koscioła dokfadnie okreslit dopiero Synod - por. W. Kasper: Sobor

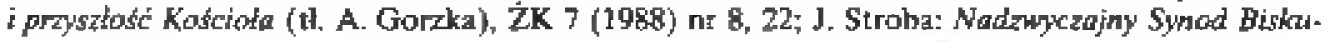
pów. Geneza - synteza - whioski $\mathbf{W}$ : W dwudzipstolecte Soboru Wablariskiego II. Recepeja doswiadczenia - perspekywy. Red. J. Homerski, F. Szulc Lublin 1987 s. 20. Pojęcie communio

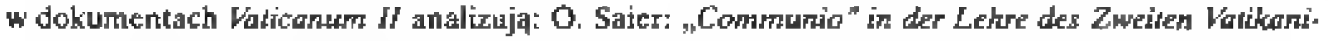
schen Konzils. Eine rechtgbegriffiche Untersuchung. München 1973; H. Rossi: Die Kirche als personale Gemeinschoft. Der komuniräre Chanaterer der Kinche Mach den Dokumenren und Aken des Zweiren Vorikanischen Konzils. Köln 1976. 
ne w interpretacje genezy i misteryjnego wymiard Kotciota (por, KKK 759-769, 772 $\mathrm{n}$, $775,781-789,797 n$ ); w dialogu ckumenicznym znaleźc je mozna w kilku dokumentach (zwłaszcza w dokumencie dialogu katolicko-prawoslawisego z Monachiun $\mathrm{Mi}$ -

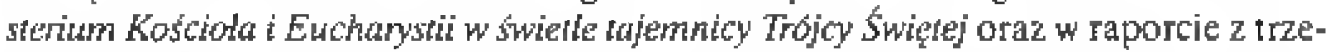
ciej fazy Międzynarodowego Dialogu Luterańsko-Rzymskokatolickiego Koficít

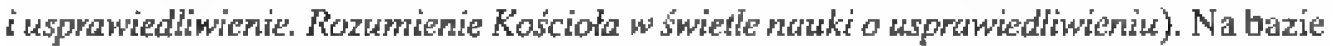
kategorii communio rozwija sję jeden z modeli jednosci Kościolów. Poustają też prace, które wskazują na doniosłose ekJezjologii communio ì szanse, jakte stwarza dla dialogujacych z sobą chrzescijan².

Papiez Jan Paweł II elementy rozumienia Kosciota jako komuni kresli w Adhortacji apostolskiej Christfdeles latci (por. CL 18-31); w Nowo Milennio Mewte zakjada je, rozwija (wypowiadaje jczykiem bardziej duszpasterskim) i na nich buduje. Cznnic Kościól domem i szkola komuni - to zdariem papicza - wielkie zadamie, jakie czeka nas w rozpoczynajacym sie bysiqcleciu, jeśli chcemy pozontaf wierni Bozemu zamystowi, a jednoczesnie odpowiedzlec na najglebse oczekiwania swiala (NMI 43).

I whaśnie w takiej perspcktywie zamierza sié przedstawić te najbardzicj podstawowe prawidta urzecrywistniania się i wzrostu komunił Kościola. Chodzi o elementy posoborowej eklezjolugii communo, w swietle klorych petniej wybrmiewa papieskj program odnowy Kotcioła.

\section{Istota eklexjalnej komunii}

Słowo communia nie wyraza na pienwszym miejscu struktury Kościola; w\$skazuje raczej na źródto, z którego Kosciol bierze poczatek i dla ktorego ży e"; wypowiada mistenium Kosciola w biblijnym rozumieniu tego stowa, tzn. transcendentna rzecywistośc zbawczą, ktora w widzialny sposob siç objawia. Chodzi mianowicie o dar osobowej więzi czlowieka z Troj]edyny Bogien i z innymi Iudźmi, wiezi zapoczatkowanej przez wiarę i skierowarej do pelni eschatologicznej (por. CN 3).

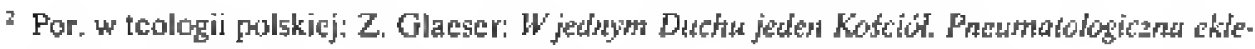

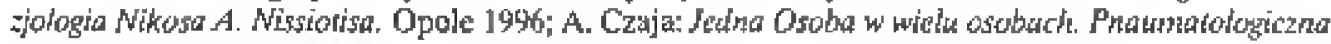

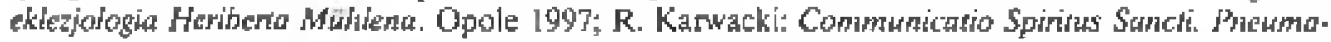

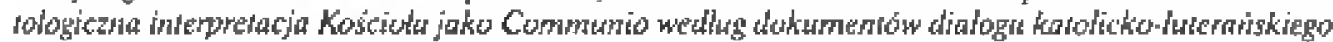

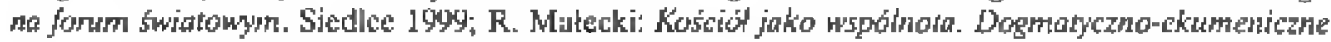
stwdiwm eklezjologil Johna Ziziowlago. Lublin 2000.

'Analizując Pawtowe rozumienie koinonia Rudolf Schnackenburg przckonuje, ze ,chret-

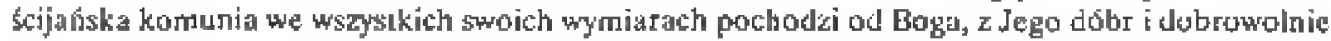

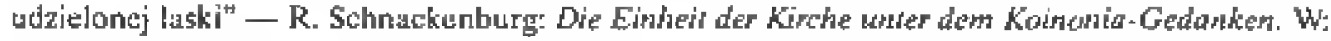

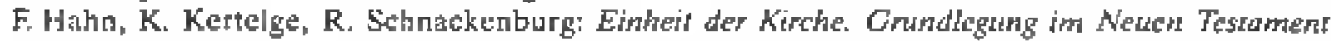
[OD 84y. Freiburg Basel Wien 1979 5. 62. Sehnackenbugg podkreśa In rowniez, ze u podstaw owej komusij jesl - zgodnie a 1 Kor 1, 9 - Boskie powolanic nas do wepólnoly a Jezusan Chrystisern. 
Jako taka, komunia Kościoła ma swą podstawę w porządku stworzenia i stanowi ostatcczną formę realizacji zbawczego planu Boga ${ }^{5}$. Jego odwiecznym zamiarem jest obdarowanie ludzi udziałem w Boskim życiu i zawiązanie przez to wspólnoty (por. 1 Kor 1,$9 ; \mathrm{KK} 2$ ). Wielokrotnic wskazują na to soborowe dokumenty, mówiąc o powołaniu człowieka do wspólnoty z Bogiem (por. KDK 19, 21, 24), czy o wspólnocie z Bogiem jako zasadniczym celu Chrystusowego posłannictwa (por. DM 3; KO 2) ${ }^{6}$. Z niektórych stwierdzeñ ${ }^{7}$ wynika jednoznacznie, że eklezjalna komunia oznacza na pienwszym miejscu udział („,participatio") w Boskin życiu, a przez to osobowq wspólnotę z Bogiem".

Tym samym kościelnej communio nie można zestawiać z jakąkolwiek ludzką wspólnotą, organizacją, stowarzyszeniem, czy zgromadzeniem. Nie pozwala na to jej niepowtarzalny bosko-ludzki charakter. Jej źródłem nie jest konsens, ugoda, lecz ścisłc osobowe związanic, zjednoczenie z Jezusem, którcgo wzorem, źródłem i celem jest jedność Syna z Ojcem w darzc Ducha Świętego (por. CL 18). Nie chodzi bynajmniej o wiçzy natury moralncj, lecz ontologiczncj, ponieważ spodobało siç Bogu na skutek najzupełniej wolnego i tajemnego zamysłu swej mądrości i dobroci stworzyć świat cały, a ludzi wynieść do uczestnictwa (participatio) w życiu Bożym (por. KK 2). Uczestnictwo to stanowi samą istotę eklezjalnej wspólnoty. Oznacza dostęp do Ojca przez Chrystusa w Duchu Świętym (por. Ef 2, 18)9.

- Wiele miejsca poświęca temu zagadnieniu Gerhard Lohfink. Jego zdaniem Kościót jest stwórczym dzicłem Boga, przez które chce on doprowadzić całą ludzkośc do spelnienia - por. G. Lohfink: Gortes Taten gehen weiser. Freiburg - Basel - Wien 1985 s. 17n; J. Müller: Gemeinde - Reforn? Kritisches Korreksiv oder Zufluchtsort. Wien - München 1983 s. 63n.

'Por. W. Bcinert: Das Bild von der Kirche nach den Dokumenters des II. Vatikanischen Konzils. W: Die Römisch-katholische Kirche. Hrsg. von W. Löser. Frankfurt am Main 1986 s. 30; W. Kasper: Kusciơl jako wspólnola. Refleksje nad eklezjologicznq ideq przewodniq Saboru Watykaniskiego II. Thum. J. Swicrkosz. ComP 34 (1986) s. 29n.

- Mysl ta jest wyraźnic obecna w: Katholischer Emachsenen-Katechiumus. Das Glaubensbekenntnis der Kirche, hisg. von der Deutschen Bisclwofskonferenz. Bonn 1985 s. 116, 123-126. Por. polskie wydanic: Katolicki kalechizm dorasjych. Wyznanie wiany Kasciola. Puznan 1987 s. 113, 120-123. Zob. KKK 27.

'Por. O. H. Pesch: Das Zweire Valikanische Konzil (1962-1965). Vongeschichie - Verlauf Ergebnisse - Nachgeschichle. Würzburg 1994' s. 186-188.

"H. Düring: Die Communio-Ekklesiologie als Grundmodell und Chance der ökumenischen Theolugie. W: Communio Sanctorum. Einheit der Chnisten - Einheil der Kirche. Hrsg. von I. Schreiner, K. Wittstadı (FS P.-W. Schecle). Würburg 1988 s. 442. W: Katholischer Enwachsenen-Katechismus (s. 65) czylamy: "So war man in der Kirche von Anfang an überzeugt, daß eigentlich und spezifisch Christliche in einer intimen persönlichen Gemeinschaft mit Gott besteht und im Wissen Kind, Sohn, Tochter Gottes zu scin”. Polskic tlum., s. 64. Por. P. Neuner: Ekklesiologie - Die Lehre von der Kirche. W: Gluubenszugänge. Lehrbuch der Katholischen Dogmatik. Hrsg. von W. Beinert. Bd. II. Paderborn - München - Wien - Zürich 1995 s. 461. W nawiazzaniu do KK 2: „Przedwiccıny Ojciec [...] stworzyl świat caly, a ludzi postanowil wyniesć do uczestnictwa w życiu Bożym" Walter Kasper zauważa, ze Dei verbum określç tẹ partycypację wspólnotą osobowa (socięas; KO 1,2), natomiast Ad gentes wyraża ją terminami pax i communio (DM 3) - por. art. cyt., s. 67.

- Miguel Garijo-Guembe pisze: „Mit dem Begriff Communio/Koinonia ist die Tcilhabe am Leben Gottes durch Christus im Heiligen Geist gemeint" - Tenże: Communio-Ekklesiologie. Zum Schreiben der römischen Glaubenskongregation über einige Aspekse der Kirche als Communio. US 47 (1992) s. 323. Zdaniem P.W. Scheele: .Die Gemeinschaft der Heiligen ist eine gnadenhaft geschenkte Gegebenheit; sie gründet in geheiligten Gaben Gottes und mündet in geheiligte Menschen, die nach dem Willen des Vaters durch Christus im Heiligen Geist mit dem dreifaltigen Gotl und untereinander verbunden werden" - Damit auch wir Gemeinschaft mit uns habt. Konzilsimpulse für herute. Würzburg 1993 s. 53. Por. Müller, dz. cyt., s. 250-252. 
Chodzi o to, źe komunia Boga z człowiekiem, wcześniej zupclnie nie do pogodzenia z transcendencją Boga'", ma swoje jednorazowe historyczne urzeczywistnienie w Jezusie Chrystusie". On slanowi szczyL wszelkiej komunii między Bogicm i człowiekiem ${ }^{12}$. Przez Niego wszechmocny Bóg (...) w nadmiarze swej milosici zwraca się do ludzi jak do przyaciót i obcuje z nimi, aby ich zaprosid do wspólnoty z sobq i prayac ich do niej $(\mathrm{KO} 2)^{13}$. W ten sposób *wspolnota Bostwa i Cztowieczersista w Chrystusic staje się podstawa wkonstytuowania nowej wspólnoty whistorii zbawienia ${ }^{\text {l\$. }}$. Przez swoje wciełenie Boż Syn jednoczy się jakos z każdym człowiekjem (por. KDK 22), a przez to nowy związek w Chrystusie otwiera się i rozciąga na nowy związek ludzi międdy sobą (por. CN 3) ${ }^{\text {ls. }}$. Rozwija się komunia żywa i ozywiająca, klóra sprawia, że chrześijanie są wasnoscią Chrystusa, jak latorosíl wszczepiona winny krzew (por. CL 18).

O jedności chrześcijan między nirri, a najpierw jeszcze z Chrystusem stanowia

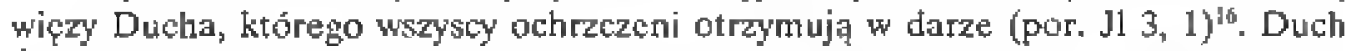
Swięty, zrealizowane w Chrystusie doskonate zjednoczenie Boga i czlowicka, od wewnąltz urzeczywistnia i rozszerza'. On wszczepia ochrzczonych w Chrystusa (por. J 15, 1-10). Dzięki Niemu jest udziałem chrześcijan szczególny rodzaj inegzystencji w Chrystusie. Obiecane tedy odnowiente, ktorego oczekujemy - wyjaśniają ojcowie soboru - jui sie rozpoczęlo w Chnstusie, posteppuje dalej w zestaniu Ducha Swietego i prez Niego trwa w Kosciele (KK 48).

an Por. "In der Fleiscliwerdung des ewigen Worles wollzieht sich jene Kommunion zwisehen Gott und dom Sein des Menschen, seiner Kreatur, die worber mil der Tranßeadenz des einzigen Gottes unvercinbar schien" - J. Ratzinge: Kommunon - Kommunilär - Sandung. Über den

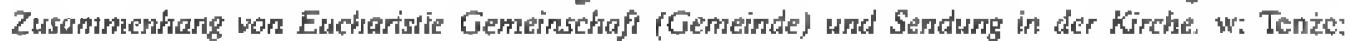
Sehowen auf den Durchbohrien. Verwche zu einer spirituellen Chrstologie. Einsicdeln 1984 s. 73.

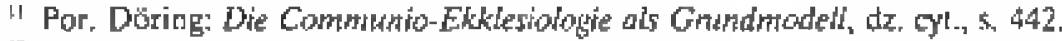

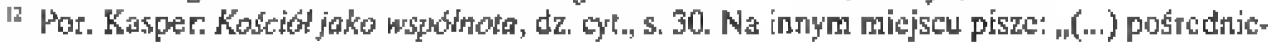
two, które dokonato siç w Jezusie Chrystusic, nie jes: sprecterc a istota czlowieka, lece jest jej

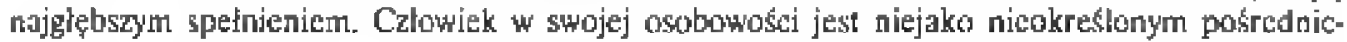
tumen między Bogiem a człowjekiem; osigga ono Jezusie Chrystusic swoje okreslenje, swoja petnię i swoje spetnicnie. Dlatego Jezus Chrystus w swojej osobit jest zbawitnien czlowitka" -

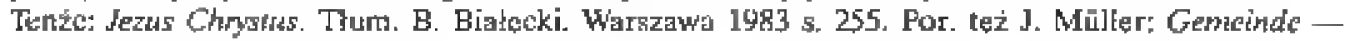

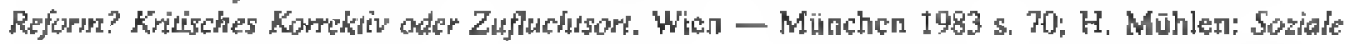

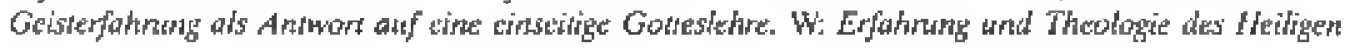
Geisfes. Hrsg. w. C. Heimang u. H. Mühlen. Hamburg - Munchen 1974 5. 267.

J9. Por. Greshake: Der dreieinige Gout, dz. cyt., 5. 318, prypis 271.

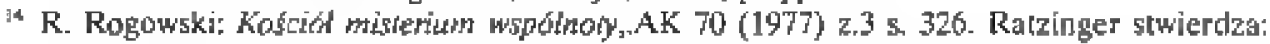

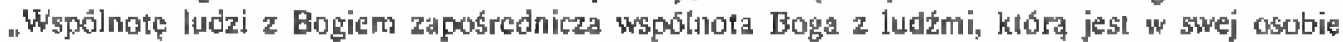

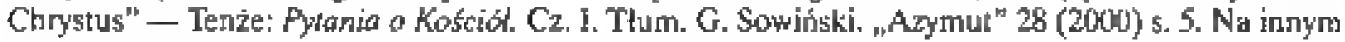
miejscy wjasnia: "Der Fleischgewordene Sohn ist die "Kommunion twischen Golt und den Menschen. Christsein ist in Wahthcit nichts anderes als Beteiligung am Geheimnis der Inkatnation (...) - Tenzer Kommumion - Kommuniti' - Sendung, dz. cyt, s. 74.

13 Klaus Hemmerle pisze: „Jesus ist die Geschichte Gotles mil den Menschen, er ișt die Einheit aller Menschen mit Gott und miteinander, (...) Whahrhaft, er ist der Bund zwischen Gotl und den Menschen und der Bund zwischen allen Menschen in suiner Person" - Tenze: Wie

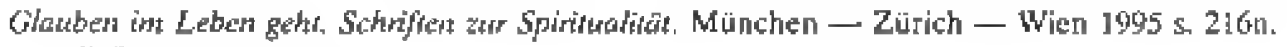

15. Por tamze, s. 217.

1" Pisze Otto Hermann Pesch: "Diese Vereinigug wird fortgefirt, van imen verwirklicht und

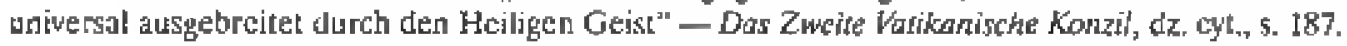


W ten sposbb egzystencje kościelnej communia Trójedyny Bóg dwojako warankuje. On jest źróltem jej zaistnjenia i jest źródtem jej trwania. Innymi stowy: z jednej strony koscichna komunia wyrasta ze stwórczo-zbawczej i uswięcającej aktywnósci Trzech Boskich Osób, swoj poczqlek bierze wodle plamu Ojaca z postania Syna i z postania Ducha Swiętego (DM 2y; z drugiej strony jest zywa i ozywiająca dzięki Bozemu samoudzielaniu sie, drięki obdarowywaniı sobą - wasną trynitarna communo. Jako taka stanowi ind zjednoczony jednosia Ojca is Syna i Ducha Swięfego (KK 4; por. DE 2; KKK 813)"

Przez partycypacje w tryitanej komunii powstaje w Kościele, analogiczna do trynitarnej, jednośc i wspólnota. Przygotowany, umozliwjony i nacechowany prez komunic trynitarna, stanowi Kosciol jednos w wielosci czlonkow, wielos w jednosei jednej substancji wiary, nadziei i milosci. Więcej nawot, poniewaź w sakramentalnoznaknwy sposob uobenia Irynitarna konunie, zwlaszca w zgromadzeniu eucharyslycznym, godzi sic w nim widzied ikone Trojoy Swiętej"

Dla postrzegania Kościoła, a także dla jakiejkolwiek dziatalnosci na rzecz wzroslu Kosciola ma to pierwszotzęne znaczenje. Eklezjană wspolnota nie jest ptzejawera hakicj aktywnosci, lecz owocem Boskiej inicjatywy ${ }^{22}$. Jest Bozytn darem, wielAim darm Drefa (CL 20). On jest pjerwszm Budowniczm, jodynym Ozywicielem Kosciok. Dlatego zadaniem ras wsystkich jest ciagłe prywohyanie Bozego Ducha i wcielanie w zycie tego, co mówi do Kasciolow (por. Ap 2-3).

\section{Zyciodajne środki koscielnej komunii}

Zuiczła interpretacje ureczwistniania sieklozjalnej komunil predstawia soborowy dekret o apostolstwie świeckich: (..) zoie whajglebsym zjednoczenit z Chrystugem w Kosicle podtrymuja pomoce duchowe, wpolne wrysthim wiemym, zwhas.

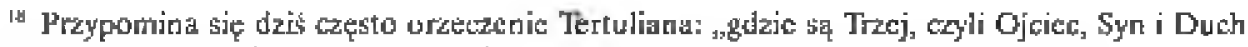

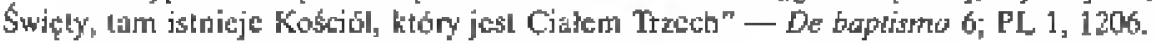

19 W. Kasper pisze wprost: "Die Kirche ist gieichsan die Ikone der trinjtarischen Gemein-

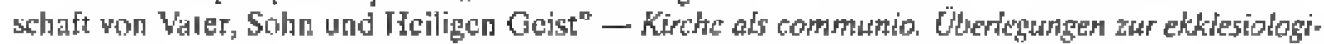

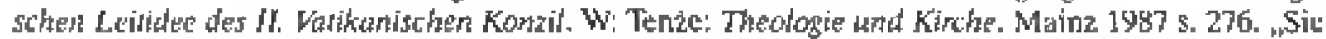
[dje Kirche! ist Ikone der Trinität, [i dalej] Einheje in der Vielfal" der Glieder, Vielfal"t ith der Eipheit der eisicn Suhstanz des Glabbens, dor Holfnung und dęr Liębe, Wir kinnthen sogar sagen: Das Mysterium der Kirche is: das Shrer communio, weil sie sakramentat-zeichenhaft Vergegewijti-

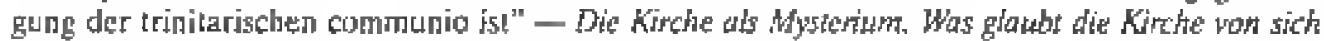

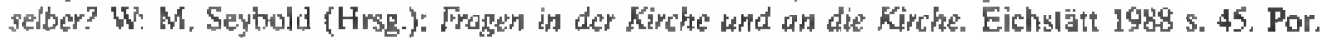
Döring: Die Communto-Ekhlesiologitw, dz. cyt. s. 442; H. Potmeyer. Der Heilge Geigt and die Kinche.

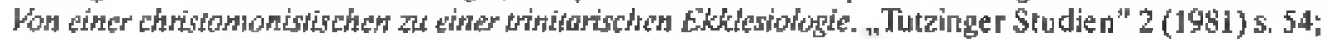

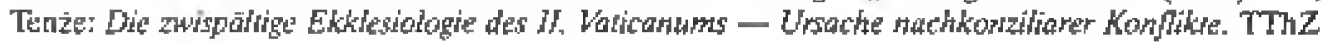

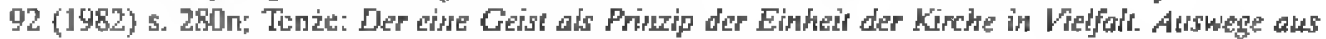

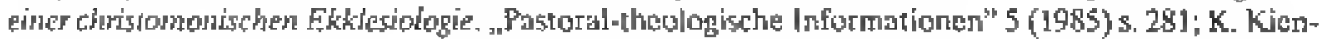

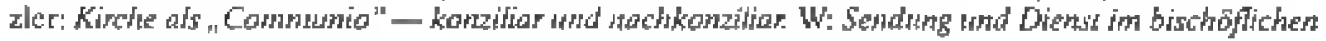

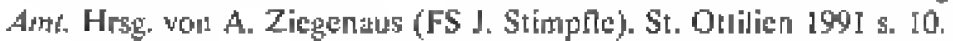

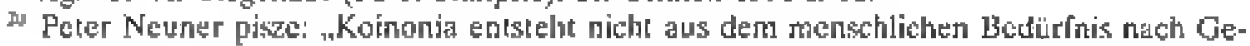
borgenheit, sondem als gōttliche Gabe und Geschenk" - por. Ekhlediologie - Die Lefre won der

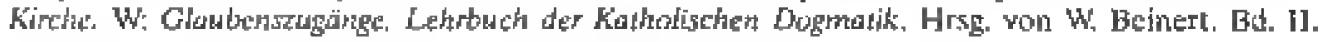
Pâderborn - München - Wien - Zūriciı 1995 s. 461.
} 
cza czynny udziat w świętej liturgii (DA 4). To samo wyraża synodalne Relatio finalis: zjednoczenie z Bogiem przez Jezusa Chrystusa w Duchu Świętym dokonuje się w slowie Bożym i sakramentach (RF II,C,1).

W komentarzach posoborowa eklezjologia odwołuje się do pojęcia communio sanctorum znancgo tradycji patrystycznej ${ }^{21}$. Oznacza ono (w pierwszym tysiącleciu chrześcijaństwa) nie tyle wspólnotę, co udział w dobrach zbawienia, współudział w tzw. „rzeczach świętych” ofiarowanych przez Boga ${ }^{2}$. Chodzi o Bożą prawdę i Bożą laskę. Duch Święty obdzielając nimi daje udział w Boskim życiu, gdy człowiek (również za sprawą Ducha) przyjmuje w wierze słowo Boże i święte sakramenty ${ }^{23}$. Owocem jest communio sanctorum w znaczeniu preferowanym w II tysiącleciu chrzescijaństwa; powstaje więź jednej milości pośród wszysıkich wiemych na tym i na tamtym świecie (CL 19), tzn. kościelna wspólnota pielgrzymujących na ziemi, poddających się oczyszczeniu i zażywających chwaly (por. KK 49). Chrzest jest jej bramą i fundamentem, Eucharystia - źródłem i szczytem (por. RF II,C,1) 24 .

23 Po raz pierwszy wyrazenia communio sanclonum uływa św. Hieronim - zob. Ep. 17,4, PL 23,360n; cyt. za H. Schütte: Kirche im ökumenischen Verständnis. Kirche des dreieinigen Gottes. Paderborn 1992' 5. 45. W IV wieku wprowadzono je do wyznania wiary. Wyniki wnikliwego studium na temat historycznego rozwoju rozumienia communio sanctorum przedstawia Manucl Gesteira w artykule: Wierzę w swiętych obcowanie. Tlum. G. Ostrowski. ComP 51 (1989) s. 3-39; zob. s. 17-20.

" Communio oznacza pierwotnic uczestnictwo (panicipatio), a dokładnie "współudzial w owocach zbawienia udziclonych przez Boga", dopiero wiórnie wspólnote - Kasper: Kosciól jako wspólnola, dz. cyt., s. 31; por. R. Karwacki: Znaczenie stowa communio. "Studia Podlaskic” 9 (1994) nr 2 s. 124-140. Zdanicm Ratzingera ten stan rzeczy ilustruje dobrze Lukaszowy opis powolania uczniów, w którym Jakub i Jan sq okresłleni wspólnikami Szymona. Wynika zen, ze Szymon, Jakub i Jan ksztaltują towarzystwo wspólników, ludzi partycypujących we wspólnych dobrach, pracy, warto. ściach. Dlatego, wyjaśnia dalej, z momentem, w którym Jezus mówi do Szymona: odı̨qd ludzi bedziesz lowil ( Kk 5, 10) powstaje nowe lowarzystwo, nowa wspólnota skupiona wokól udziału w nowej aktywnosci; wspólnota na rzecz lowienia ludzi. Określa ją Ratzinger "towarzystwem malej łódki Kosciola" - por. Tenże: Kommunion - Kommunirät - Sendung, dz. cyt., s. 69n.

23 Słowo i sakramenty interpretuje się jako środki konstytuujące eklezjalną wspólnotę — por. P.-W. Scheele: Damil auch ihr Gemeinschafı mit uns habt. Konzilsimpulse für heute. Würzburg 1993 5. 64-72; H. Schürmann: Anamnese als kirchlicher Basisvorgang. Eine theologische Besinnung. W: Communio sanctonum. Einheit der Christen - Einheit der Kinche. Hrsg. von J. Schreiner, K. Wiltstadt. Würzburg 1988 s. 100-102.

24 Por. W. Fürst: Communio als Prinzip pastoraler Theologie und pastoraler Praxis. LS 37 (1986) s. 238-240; I. Riedel-Spangenberger: Die Communio als Strukturprinzip der Kirche und ihre Rezeption in C/C/1983. TThZ 97 (1988) s. 220-222; J. Ratzinger: Kommunion - Kommunität Sendung. Über der Zusammenhang van Eucharistie Gemeinschaft (Gemeinde) und Sendung in der Kirche. W: Tenze: Schauen auf den Durchbohrien. Versuche zu einer spirituellen Christologie. Einsiedeln 1984 s. 62-74. Kasper pisze: „Koinonia/Communio bedeutet ursprünglich nämlich nicht Gemeinschaft, sondern participatio/Teilhabe, năherin Teilhabe an den von Goll geschenkten Gütern des Heils: Teilhabe am Heiligen Geist, am neuen Leben, an der Licbe [...]" - Kirche als communio, dz. cyt., s. 69. Do takiego ujęcia przyczynily się niewątpliwie prace biblistów analizujące rozumienie koinonia w Nowym Testamencie, zwlaszcza w listach Sw. Pawla - por. tamże, przyp. 9. Wedlug Josefa Hainza "ist koinonia im Anschluß an paulinische Aussagen der Vorgang der sakramentalen Teilhabe an Golt und die dadurch gewährie Gemeinschaft mit ihm und mit allen, die in gleicher Weise teilhaben, d.h. koinonia ist die Gemeinschaft mit jemandem durch gemeinsame Teilhabe an etwas" - Tenże: Koinonia. "Kirche” als Gemeinschaft bei Paulus. Regensburg 1982 s. $34 n, 89$. 
Na zieni wspólnota ta rozwija się w "przestrzeni" wiary. Albowiem Hierzyć w Trójjedynego, Jemu poddấ swoją egzystencję poprez zjednoczenie z Jezusem Chrystuscm, oznacza z koniecznośl wstąpić w Boską komunię, a wtónie zwił̨"ać się z tymi, którzy wazaz z Chrystusen-Glową, będąe juź czlonkami Ciała, uzzecrywstniaja "Calego Chrystusa" (totus Christus). Po prostlu cztowiek nie mozie osobno wierzyc. Nie moze też sam z siebie wierzyc. I nie chodzi tylko o to, że wiara jest w swej istocie laską. Czlowiek wierząc pozwala się waączyć w to, co we wspólnocie już obowiązuje, przyjmuje warunki określające tożsamośe wspólnoty. Dzięki temu zostaje do wspólnoty whaczony, a akt ten nie jest następstwem, lecz częscią wiary, ponieważ ta jest zarb́wno osobistym aktem wicrzącego, jak i kolektywnym aktem Kościola. Wiafa ma wyraźnie eklezjotwórczy charakter i to mają na uwadze ojcowie Soboru, gdy upatruja w Kosciele zgromadzenie tych, co z wiana spoghtqaja na Jezusa (KK 9). Można powtóIzyć za Ratzingerem: Kosciól najbardziej jes' nie tam, gdzie się organizuje, reformuje, raqdzi, nilko w wch, ktorzy po prostu wiena i w nim prymuja dar wiary, kióny staje się dla nich zyciem ${ }^{2}$.

Wynika z tego, że kościelna komunia o wiele bardziej domaga się przyjęcia, aniżeli organizacji. Jest w swej istocie darem, którego nie można sobie udzielić (podobnie jak w proypadku sakramentów). Rozwja się z przyjęcia w wierze Bożej laski i Bozcj prawdy. Urzeczywistnia się tylko tam, gdzie czlowiek posiada udzial w "rzeczach \$więtych", tzr. we wszelkich darach Ducha, a nade wszystko w Nim sarnym, ponicwaz jest nie ty]ko Dawcą, ale i pierwzym Darem. "Posiadanie" Ducha stanowi pierwsze kryterium przynależności do Chrystusowego Kościoła (por. KK 14-16), zgodnie ze stwierdzeniem KK 49: Wszysy bowiem, który sq Chrystusowi, majac Ducha Jego zrastajq sie w jeden Kosciot i zespalaja sie wzajemnie ze soba $w$ Chystusie (por. E[ 4, 16) ${ }^{26}$.

Posiadanie udziahu (Teilhabe) w dobrach zbawienia wymaga uprzedniego Boskiego obdarowania (Teilgabe), ale też przyjęcia daru przez człowieka (Teilmahme)" Potrzeba by czlowiek wziąt w swe rẹce stworzoną mu przez Boga możliwość udzialu w dobrach zbawienia. Wymaga to od każdego $\mathrm{z}$ nas gotowości do aktywnego uczestrictwa (participatio actuosa); nasz wspótudzial domaga się wspóldziałania ${ }^{23}$. Dlatego w kosciefnym przepowiadaniu duszpasterze powinni ksztaltowac u wiernych solidna motywację korzystania ze stołu slowa Bożego i ze skarbricy swiętych sakramentow. Nas po prostu nie stac na marnotrawstwo Boskich darów. Potrzeba też głębszej re-

75. Jatzinger: Whowadzenie w chzéreljansfwo. Krakow 1970 g. 288.

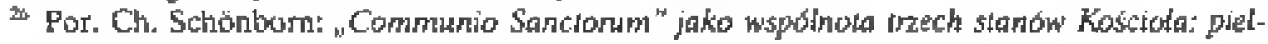

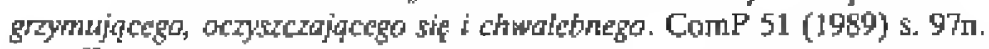

${ }_{27}$ B.J. Hilberath wyjasnia: „Der dreicinige Goth schenk: uns scine Gemeinschaft, das ist Teilgabe "dadurch werden wir zu einer Gemeinghaft, das ist Teilhabe; diese realisiert sich als Gemeinschatt, in der alle auf inre Weise an der Sendung Icilmelmen" - Kirche alt communio. Beschworngsfomel ader Projekbeschreibung? ThO 174 (1994) s. 52, prayp. 22.

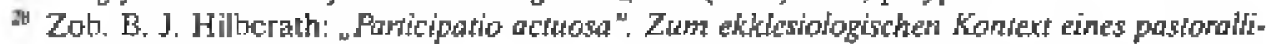

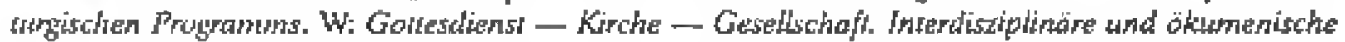
Standortbenimmumgen mach 25 Jalmen Liturgiergom (Pielas liturgica 5). Hrsg. won H. Becker, B. J. Lilberdth, U. Willers. SI. Ottilien 1991 s. $3.19-338$. 
fleksji nad samymi źródlami, z których eklezjalna wspólnota czerpie życie, nad słowem Bożym i nad sakramentami. W sposób szczególny chodzi o pogł̨̨bienie uczestnictwa w Eucharystii, która jest siłq tworzq̨cq komunię między czlonkami Koscioła, dlatego że jednoczy każdego z nich z Chrystusem (CN 5); jest sakramentem za pośrednictwem, ksórego w tej samej chwili tạczy się caty Kościóf?.

\section{Struktura komunii Kościoła}

Kościół pielgrzymujący na ziemi rozwija się jako braterska wspólnota wszystkich wiernych (por. CL 18-20) i równocześnie jako wspólnota Kościołów lokalnych (por. Communionis notio, 7-10), a mianowicie w tej samej wierze, wspólnym chrzcie, w Eucharystii i w Episkopacie (Communionis notio, 11) ${ }^{30}$. Jako taki urzeczywistnia w swej strukturze katolicka jedność, tzn. wielość $i$ zróżnicowanie, które nie przeszkadzaja jednosci, ale nadaja jej charakser „komunii ${ }^{31}$. Jest to jedność w różnorodności wiernych (communio fidelium) $\mathrm{i}$ jednosć w wielości Kościołów lokalnych (communio ecclesiarum), której centrum stanowi Chrystus-Głowa reprezentowany w mocy Ducha przez wspólnotę pasterzy (communio hierarchica) $)^{32}$.

\section{Braterska wspólnota wiernych}

Soborowe tcksty mówią wyraźnie o communio fidelium zaledwie w kilku miejscach i to raczej w wieszczący sposób (KK 13; DE 2; DA 18) ${ }^{33}$. Z całości soborowego nauczania wynika jednak, że chodzi o najbardziej podstawową formę struktury Ko-

21) Sw. Augustyn: Contra Faustum 12,20.

to Kasper wyjaśnia, że „gdyby jednośc Kościoła opierala się tylko na jednej jedynej 'zasadzie' [np. prymat papieża], musiałaby być totalitarną jednością. Ponieważ przeciwnie jednosć jest ugruntowana na relatywnie róznych 'zasadach' $i$ ich 'wspóldzialaniu', dlatego Kosciól jest otwartym systemem" - Diensi an der Einheit, dz. cyt., s. 31.

11 Jan Paweł II: Przemówienie w czasie audiencji ogólnej (27 wrzesnia 1989), 2: Insegnamenti di Giovanni Paolo II, XII/2 (1989) s. 679; cyt. za CN 15. Beinert zauwaza: „Communio ist, wie es in der neuen Konfessionskunde des J.A. Möhler-Instituts in Kennzeichnung des Charakteristikums katholischer Kirchlichkeit heiBt, 'nicht nur das Lebensgesetz der inneren Wirklichkeit der Kirche, sondern auch das Strukturprinzip ihrer sichtbaren Verwirklichung in Welt und Geschichte. Weil Kirche ihrer inneren Wirklichkeit nach Communio ist, sind auch Gestalt und Ordnung der sichtbaren Kirche kommunional strukturicrt' " $-W$. Beinert: Der Heilige Geist und die Sirukiuren. Die Spannung von Ams und Charisma in der Kirche. W: G. Koch, J. Pretscher (Hrsg.): Wo der Geist des Herrn wirkt, da ist Freiheit. Würzburg 1997 s. 91. Por. G. Hintzen: Die katholische Kirche W: J.A. Mohler-Institut (hrsg.): Kleine Konfessionskunde. Paderborn 1996 s. 33.

12 Por. Kasper: Kasciót jako wspólnota, dz. cyt., s. 34-41; Döring: Die Communio-Ekklesiologie, dz. cyt. s. 444-448; Riedel-Spangenberger: Die Communio als Struksurprinzip der Kirche, dz. cys., s. 230n; M.M. Garijo-Guembe: Gemeinschaft der Heiligen. Gnund, Wesen und Struktur der Kinche. Düsseldorf 1988, zwlaszcza S. 118-137, 145-214; Tenże: Communio-Ekklesiologie. Zum Schreiben der römischen Glaubenskongregation, dz. cyt., s. 324-327: Scheele: Damis auch ihr Gemeinschaft mir uns habt, dz. cyt. s. 73-82.

3) Por. Kasper: Kościot jako wspólnota, dz. cyt., s. 39; Döring, art. cyt., s. 446. 
ścioka, którą ksztaltują wszyscy wiernit. Jej czlonkiem staje się czlowiek z momentem prayjęcia chrztu świętego. Wówczas zostaje wszczepiony w Chrystusa, jego udziafem staje się Jezusowe namaszzzenie Duchem Swiętym i zostaje whączony we wspolnotę chrześcijan (christionoi, tzn. namaszczonych — por. Dz 11, 26).

W dekrecie Presbyteronum ordinis wyjäsnia się rzecz następująco: Pan Jezus, whtó rego Ojciec uswięcit i postat na swiat ( 10,36 ), czyi uczestrikiem namaszczenia Ducha Swięrego, któnym zostal pomazany (por. $M t 3,16 ; \pm k 4,18 ; \mathrm{Dz} 4,27 ; 10,38$ ) cale swoje Cialo Mistyczhe; $w$ Nim wszyscy wiemi shajq sie stwiegm i krolewskin kaplahstwent, sktadaja Bogt duchowe ofiary przez Jezusa Chrysiusa i glosza wspaniate dzieta Tego. kiony ich wezwal $z$ ciemnosei do przedziwnego swojego swiatla (DK 2$)^{35}$. Z tekstu wynika, ze wszyscy wierni jako namuszczeni Duchen \$więrym ksztattują mesjafiski lud Boży. $Z$ racji wszczepienia w Chrystusa na swój sposób uczestniczą w Jego potrójnej misji kaplańskiej, prorockiej, królewskiej i odpowiednio do zajmowanej pozycji să powołani do wypefniania poslania, jakie Bíg powierzył Kościolowi w \$wiecie (zob. KK 31; KKK 871).

Realizacju posłannictwa polega w grumcie rzeczy na realizacji potrójnej misji Chrystusa (por. KK 35-37): misji kaplańskiej - przez ofiarowanie Bogu sicbie i swojej aktywnostci, risji prorockiej - przez postuszeñstwo Ewangelii, odważne gloszenie jej w środuwisku żcia i pracy oraz misji królewskiej - przez służbę na rzecz wlączania šwiata i cztowicka do królestwa Bożego poprzez przesycanie Ewangelią struktut polityczrych, systemow spoteczno-gospodarezych i kultury. Sa to zadania wszystkich wiernych, tak świeckich, jak i duchowsych oraz osób konsekrowanych ${ }^{39}$.

Jeden i ten sam Duch we wszystkich wiernych (w Glowie i czlonkach; KK 7) jest podstawą i źródłem ich godnosei i braterstwa; czyni wszystkich braćmi i siostrami Jezusa, przybranymi dziećmi jednego Ojca; kształtuje wspólnotę równych, mimo zróżnicowania urzędow, charyzmatów ; funkcji. Dlatego we wspólnocie wiernych nie

4 Pisze Kisper: „Dic Kirche und ihre Gemeinden werstanden sich von Anfong an als einen cinzigen Leib, is dem jedes Organ seitnen spezifischen Dienst am Ganzen besilat ( 4-31). Hier kann weder jedes alles, noch kömnen alle al les seìn. Alles körnen nur alle sein, und die Einheit aller ist ein Ganzes. Das jsı nach cinen berühnten Wort won Johann Adnm Möhler die Ijlec der katholischon Kirchc- Sie is weder klerikale Kirche "won oben", noch laikale Kirche "won unten". Sie ist ein gegliedertes und differenziertes Ganzes, eine lebendige Communio-Wirklichkeit" - Bernffung und Sendang der Laien, dz gyt., S. \$81. Por. J.A. Mobler: Die Einhein in der Kirche oder das Prinzip des Katholizismus (IB25). HIsg. won J.R. Geigelmann. Darmstadt 1957 5. 237.

15 W komentarzu do tego tekstu Mühien wyjasnia: .Sowohl das allyeraejne, als auch das besondere Prjestertum ist also veranden als eine Teilnahme an der Salbug Jesu mit derm Heiligen Güstc, und zwas so, dab dic gewtithen Priester in persona Christi handeln können und dürfen. (...) Das agere in persona Chriski ist nämlich etwas gänzlich anderes als ifgendein myslizisrisehes esse persona Cluristi. Wenti das Konzil atso das Priestertum in der Kirche ausdrucklich als eine

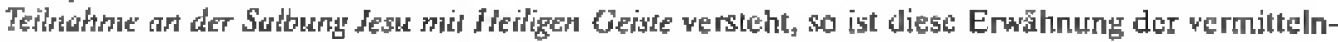
den Furktion des Geistes Christ nichl irgendeine Verzierung oder aus der Bemühen erwathsen, den Heiligen Geist auch irgendwann einmal zu erwähnen, sugden es fiandelt sich bier um eine für die Kirche kortstutive Gegebenhoit" - Una Mygtica Rersona Die Kirche als dar Mysterium der

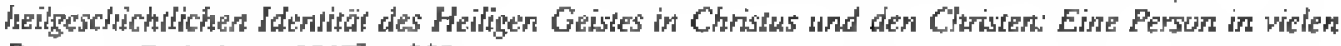
Personem. Paderbotn 19677 5. 383.

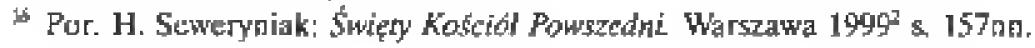


ma podziału na członków lepszych i gorszych, aktywnych i pasywnych; nic ma żadnej linii podziału między duchownymi a swieckimi. Wszyscy są duchownymi we wczesnochrześcijańskim rozumieniu jako obdarowani tym samym Duchem. Wszyscy maja udzial w jednym zbawczym poslannictwie Kościoła, w byciu znakiem i narzędziem zbawienia dla świata; sa powołani do świętości, do współodpowiedzialności i podmiotowego bycia w Kościele; kształtują komunię wolności, równości i braterstwa w jednej urzeczywistnianej przez Ducha wierze i w różnorodności rozdzielanych Przezeń darów i funkcji (por. KK 32).

Tej elementarnej równości wszystkich nie przekreśla wybór i ustanowienie niektórych nauczycielami, szafarzami tajemnic i pasterzami innych (KK 32). Wprawdzie jako obdarowani szczególnym darem Ducha, władzą świçłą uzdalniającą i zobowiązującą do działania w imieniu i w zastępstwie Chrystusa (in persona Christi) Glowy i Pasterza stają niejako naprzeciw ludu (wobec Kościoła), aby karmić go słowem, umacniać sakramentami i nim kierować, nie są jednak wyniesieni ponad innych, lecz uslanowieni dla służenia wszystkim (por. PDV 15-18). (...) prawidziwa równość panuje wśród wszystkich. Albowiem rozrózinienie, kıóre położł Pan między szafaraami świętymi a reszla ludu Bożego, niesie z soba łączność, gdyż pasterze i pozostali wiemi zwiazani sq z soba przez konieczne, wzajemne odniesienia; pasterze Koscioła idąc za praykladem Pana, sobie nawzajem i innym wiemym oddaja postugi duchowe, wierni zaś ochoczo świadczq wspólnie pomoc pasterzom i nauczycielom. Tak to w rozmaitości dajq swiadectwo jedności przedziwnej w Ciele Chrystusowym: sama bowiem rozmaitość łask, posług duchownych $i$ działalności gromadzi w jedno synow Bożych, bo »wszystko to sprawia jeden i tenze Duch « [IKor 12, 11] (KK 32).

Nie może więc być mowy o rywalizacji pośród wiernych, w znaczeniu wygrywania dla siebie lepszych posad i pozycji. Rzeczą pożądaną, konieczną i jedynie słuszną jest współodpowiedzialność i współpraca wszystkich wiernych, tak w budowaniu Kościoła, jak i zbawianiu świata; zarówno na plaszczyźnie duchowej, w przekazywaniu ludziom Chnystusowego orędzia i Jego łaski, jak też iv działalności doczesnej, kıóra polega na przenikaniu i doskonaleniu duchem ewangelicznym reczywistości doczesnej ${ }^{37}$.

\section{Wspólnota Kościołów lukalnych}

Kościól pielgrzymujący jest także „ciałem Kościołów” (KK 23) i dlatego można w sposób analogiczny zastosować pojęcie komunii do jedności istniejącej pomiędzy Kościołami partykularnymi i pojmować Kościół jako communio ecclesiarum (por. $\mathrm{CN}$ 8). Chodzi o trwanie Kościola we wszystkich prawowitych miejscowych zrzeszeniach wiemych (KK 26). Oznacza ono istnienie Kościoła powszechnego w Kościołach lokalnych i z nich (por. KK 23), a równocześnie istnienie Kościołów lokalnych w Kościele i z Kościola powszechnego. Jako «części jedynego Kościola Chrystusa maja one : catościq, 10 znaczy z Kościolem powszechnym szczególny zwiqzek *wzajemnego przenikania się (jest to sformułowanie Jana Pawła II; wedlug W. Kaspcra „związek wza-

"Instrukcja o nieksórych kwestiach donyczqcych wspótpracy wiemych swieckich w ministerialnej postudze kapłanów. Wprowadzenie. W: OsRomPol 19 (1998) nr 12 s. 30. 
jemrego zadomowjenia się"y, ponieważ w kazdym Kosichele parthtilarnym jest prawdziwie obecry i dziata jeden, swiery, katolicki i apostolski Koscior Chystusowy. Stad Kosciól powszechy nie moze byc rozumiany jako suma Koscioldw lokalmych, ani jako federacja Kofiolow pamykulamych. Koschio nie jest wymiktem ich komuni, ale w swoim istotnym misteriun jest rzeczywistosciq ontologicznie i czasowo upredniq w stosunku do kazdego Kósciola panthulamego (por. CN 9).

Ontologiczna upredniosć Kościola uniwersalnego w stosunku do konkretnego empirycznego urzeczywistnienia w poszczególnych Kościolach lokalnych wynika jednoznacznie z patrystycznej mauki o tzw. preegzystencji Kościoła, czyli idei Koscioła w odwiecznym zamysle Boga. Chodzi o to, ze Kościot jeden i jedyny ontologicznie wyprzedza stworzenie it jako taki jest makk Kofciolow parykulamych, a nie ich wyworem (CN 9) $)^{39}$.

Z kolei wownętrany początek Kosciola w czasie traba wiązac z moca i dziatanicr Ducha Swiętego, które objawily sie wyraźnie w dniı Piécdziesiątricy. W relacji ș. Lukasza absolutnym początkiem nie jest pienwsza gmina jerozoljmska, lecz fakt, ze w dwunastu stary Izracl, ktory jest jeden jedyny, staje się nowym Izraelem i ze ten jeden jedyny Lzacl Boga, dzięki cudowi języków ukazuje się - zanim jeszcze doszto do powstania jerozolimskiego Koscioła lokalnego - jako jednosce, ktora obejmuje wszelki azas i wszelka przestrzer. (... nie jesl tak ze jedna gmina lokalna powoli rozszera sig, lecz bak, że zaczyn [w postaci koleginm Dwunastu - przypis AC] zawiera

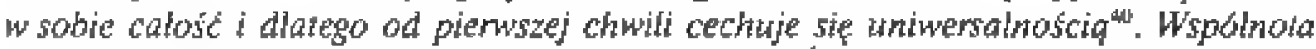

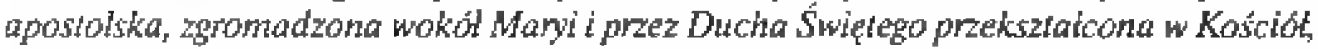
mie jest lokahym Kosciolem Jemzolmy. Każdy apostol otrymal misje powszechnq, a wrzyscy razem startowiq jeden rodzacy sip Kosciol, f... I ich prepowiadania powstaja nastepnie Kościoly partykulame, poczynajqc od Koficiola jerozolimskisgo; te ontamie to "córki it konkrethe realizacje Kóscioła powszechnego, ktory mowi wsystkimi jezykami i w ten sposob już ad poczquku swego istnienia jawi sie jako kaolicki (... $)^{\mu !}$.

Tak wicc Kofojoly partykularne znajduja I czerpia swa eklezjalnoś z Kob́ciola powsechnego. Oznacza to, ze jakikolwiek Kosciót lokalny najpelniej realizujący się w ramach liturgit nie jest caly obecry w kazdej wspólnocie celabrujacej Eucharystię. Nie wystarcza prosty akt liturgicany w odpowiednim miejseu, by uksztaltowac Kościól zaw'ze wymagana jest zasada integracji "wokól biskupa". Albowiem wspólnota sama z sfebie nie może stać się Kościolem. Níe może tak po prostu się zebrac jakas

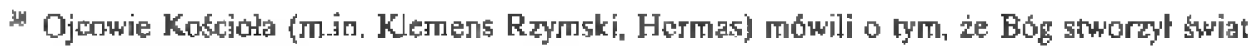

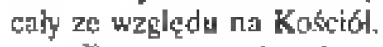

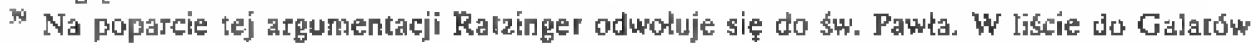
mówi on o giebicskim Jeruzalem jako o rzeczynjstosci nas poprzedzającej a nie oczckiwanej: "Natomiast góthe Jeruzalem cieszy się wolnoscla i ono jest matkq naszq" (Gal 4, 26) - por. Ratzinger: Pyamia o Kotciot, cz. I, dz cyt., s, 6 .

w" Por, tamże. Oczywiscie prawda o uprzedniosci Kościola uniwersalnego - wyjasnia Ratzin-

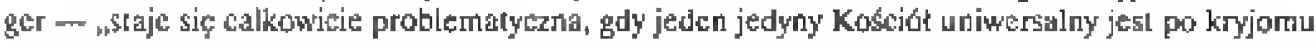
utojsamiany z Kokciolem rzymskjm, a de focho z papiczem i kuriał". Takic ujęcie aznaczaloby restauracje [xymskiego centrulizmu - por. tamies.

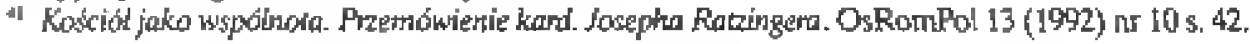


grupa, czytac Nowy Testament i ogłosić jesteśry Kosciołem, bo Pan jest tam, gdzie dwóch lub trzech zgromadzi się w Intę Jego. Raz jeszcze wraca tu zasadnicza myśl eklezjologii communio, że Kosciół jest darem i uymaga przede wszystkim przyjęcia. Można go zaș otrzymac stąd, gdzie juź jest i gdżie naprawdę jest: z sakramentalnej wspólnoty Ciała Chrystusowego przenikającego dzieje ${ }^{42}$.

Dlatego Vaticanum I/ stawia dwıstopniowe kryterium: wspólnota cefebrująca Eucharystię musi bye "prawowita", aby mogta byc Kościotem, a prawowita jest wtedy, gdy ${ }_{n}$ trwa przy swoich pasterzach" (KK 26). Chodzi zwlaszcza o biskupów, którzy jako następcy apostolow przekraczają zasadę lokalnosci. Oprócz swych lokalnych zadań, pehrią funkcję ogniwa katolickości Kościoła stanowiąc więż z Kościolem apostolskim ${ }^{4}$.

Trwanie przy swoich pasterzach stanowi także wskaźnik eklezjalnośc wspólnot parafialnych i mniejszych: tzw. malych grup, czy wspólnol podslawowych. W oderwaniu of biskupa, wzglerdnie jego przedstawicieli rozwijas się moga tylko wspólnoty schiznatyckie. Trzeba powątpiewać w eklezjalność tych wspólnot w parafiach, które działaja worew ich pasterzon ${ }^{\text {th }}$.

Ponadto, z dotychezas ornowionych elementów eklezjologii commurio wynika, ze w najmniejszych nawet wspólnotach, które chcą być Kosciolem i pragną Kościót rozwijać, nic może zabraknģ́ troski o więż z Chrystusem, o wspótdzialanic z Jego Duchem. We wspólnotach tych nie może zabraknąc almosfery braterstwa, otwarlości na swiat, misyjnego zaangażowania, skoncentrowania całej egzystencji wokól stowa i sakramentbw, zwlaszcza Eucharystii. Trzeba się też wystrzegac jakiejkolwiek wynioslości i ekskluzywizmu, gardzenia innymi wspólnotami, poczucia wyzszoscit'.

\section{Wspólnota híerarchiczncgo kapłaństwa}

Wspólnota uczniow Chrystusowych nie mozie się rozwijać bez Chrystusa, podobnic jak winna latoros!l bez zakorzenienia w winnym krzewie (l] 15, 1-10). Chodzi tutaj zarówno o żywą więź każdego ucznia z uwielbionym Panem, jak i o wiçź z historycznym Jezusem z Nazaretu, założycielem Koscioła. Innymi słowy Kósciot moze siç urzeczywistniać, i jako powszechne zgromadzenie wiernych, i jako lokalna wspólnota, wyłącznie wokót Chrystusa, w żwej łączności z Chrystusem. Oznacza to bezwzylędną koniecziność tych, którzy Chrystusá uobecniają.

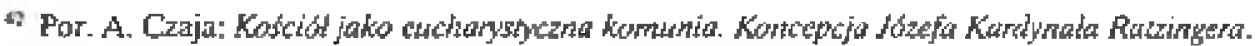
W: Imaffabile Eucharistiae Domut. Red. T. Dola. Opole 1997 s. 66.

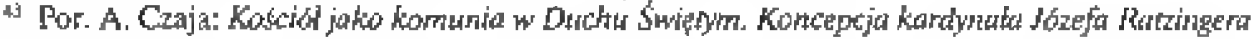

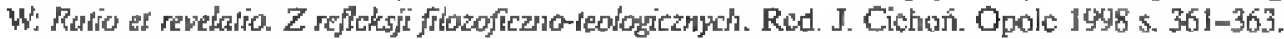

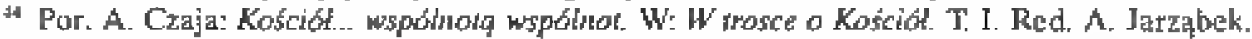
Lublin $2000 \mathrm{~s}$. 70-72. W tym kontekscie pada tez pewne swiatlo na soborowe rozrónianie peinej pranaleznosi do Kosciola, zwiazania z Kosciotem z lieznych powodów i przyporządkowanja do Kofcibla (por. KK 24-16). Staje się bardzjej jasne, dlaczego motemy mowis o Kosciolach prawoslawingh jako siosittzantych.

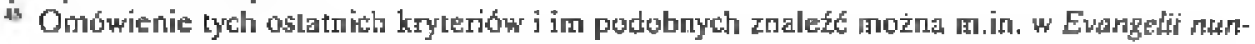
tiandi (58), Catechest sadende $(13,47,67)$ i Chrigiffidedes laici $(20,32)$. 
Tym, który nieustannie uobecnia Chrystusa uwielbionego jest zeslany przez Niego Duch Święty. W Nim Chrystus żyje i działa nieustannie pośród nas i w nas; On jest sposobem egzystencji wywyższonego Pana. Natomiası więź uczniów z historycznym hydarzeniem Chrystusa zapośredniczają Apostolowie i ich następcy, tzn. biskupi wraz ze swymi pomocnikami (prezbiterami). Podobnie jak Apostołów, Chrystus nieustannie wybiera i powołuje niektórych spośród swego ludu i obdarowuje ich szczególnym darem Ducha Świętego, który już nie tylko daje im udział w potrójnej misji Chrystusa, lecz uzdalnia ich i zobowiązuje do reprezentowania Chrystusa Glowy i Pasterza ${ }^{46}$. Kształtują oni kolegium hierarchicznego kapłaństwa (communio hierarchica), którc jako reprezentujące historycznego Chrystusa stanowi warunck konicczny egzystencji Kościoła ${ }^{47}$.

Chodzi o wspólnotę tych w Kościele, którzy w sakramencie święceń wraz z urzędem (ordo) kapłana otrzymują szczególny dar Ducha - „świętą władzę" (iurisdictio) upoważniającą i uzdalniająca do działania in persona Christi Capitis (w imieniu i zastępstwie Chrystusa Głowy i Pasterza; por. KKK 875) i wykonują tę władzę kolegialnie. Wspólnota ta urzeczywistnia się na dwóch poziomach: w Kościele powszechnym jako communio hierarchica biskupów wraz z papieżem, a w Kościele lokalnym com. munio hierarchica prezbiterów z biskupem ${ }^{48}$.

Do komunii tej nie należą diakonii. Wprawdzie w sakramencie święceń otrzymują szczególny dar Ducha Świçtego, jednak uzdalnia i zobowiązuje ich do działania w imieniu i w zastępstwie Chrystusa Sługi. Należą więc do hierarchii Kościola, ponieważ zostają niejako wyłączeni $z$ ludu i stają wobec niego, by działać w imieniu i zastępstwic Chrystusa. Chodzi jednak o reprezentowanie Chrystusa Slugi. Drogą sakramentalną otrzymują udział w diakonii Chrystusa, nie mają jednak szczególnego udziału w kaplaństwie Chrystusa".

W rzeczy samej communio hierarchica jest łaską dla całego Kościoła. Należący do niej pasterze realizują posługę słowa i szafarstwo świętych sakramenów, bez których nie można nawet pomyśleć communio sanctonum; jest gwarancją tożsamości Kościoła danego czasu z Kościołem apostolskim, a nade wszystko stanowi reprezentację, formę obecności i działania Chrystusa Głowy i Pasterza. Jako taka wspólnota hierarchiczna nigdy nie może być postrzegana jako trudny do udźwignięcia ciężar, bądź nieistotny dodatek, ozdobnik; nie jest czymś wtórnym w eklezjalnej wspólnocie;

4 "W osobach biskupów, których pomocnikami są kapłani, obecny jest wśród wiernych Pan Jezus Chrystus, Kaplan Najwyższy" (KK 21). .Prezbiterzy sq w Kościele i dla Koścjoła sakramen. talnym uobecnieniem Jezusa Chrystusa Glowy i Pasterza" (PDV 15).

${ }^{47}$ Wyraźnie na niczastępowalny charakter sakkramentalnego kaplaństwa wskazuje Instrukcja o niektónych kwesliach dotyczacych wspótpracy wiemych swieckich w minislerialnej postudze kaplanów (nr 3): ,jest ono niezbędnym warunkiem samego istnienia wspólnoty jako Kościola: Nie należy więc uwazać, że kaplaństwo sakramentalne jest (...) póńnicjsze w stosunku do wspólnoty kościelnej, tak jakby mogla ona powstać bez tego kapłaństwa. (...) jezeli we wspólnocie zabraknie kaplana, zostaje ona pozbawiona sakramentalnej praktyki i funkcji Chrystusa Glowy i Pasterza, kióra ma kluczowe znaczenie dla zycia samej wspólnoty koscieinej".

* Por. A. Czaja: Kosciol jako communio. "Pastores” 12 (2001) s. 19.

19 Szerzej na ten temat - por. A. Czaja: Diakonal w swielle nauki Katechizmu Kościola Katolickiego o irzech stopniach sakramentu swięceri. RT 48 (2001) z. 2 s. 59-66. 
stanowi niezbędny clement, conditio sine qua non życia i misji Kościoła, który realizujc się w diakonii na rzecz całości. Bez tej wspólnoty nie jest możljwe ciągłe zastawianie stołu eucharystycznego i szczególna posługa slowa przywracająca życie w sakramencie pokuty i pojednania.

Wierni włączeni do communio hierarchica nie mogą się nigdy zwalniać ze wspomnianej wyżej diakonii na rzecz całości. Do tej służby są uzdolnieni i zobowiązani. Ich byciu w Kościele musi stale towarzyszyé świadomość, żc zostali wybrani i szczególnie uposażeni nie dla wynoszenia się nad innych, lecz aby służyé Chrystusowi i Kościolowi, poprzez autorytatywne głoszenie słowa Bożego, sprawowanie sakramentów i pasterskie przewodzenie wiernym (por. PDV 74). Kolegialność w pelnicniu tej służby musi iść w parze z poczuciem osobistej odpowiedzialności za nią (por. KKK 877n).

\section{Zadania w trosce o rozwój bosko-ludzkiej komunii Kościoła}

Kościół Chrystusowy na ziemi jest jeden, święty, powszechny i apostolski. Te tzw. znamiona stanowią dobra, którymi Bóg obdarowal swoją wspólnotę raz na zawsze. Wiele jest jednak ciągle do zrobienia, gdy idzie o ich odpowiedzialne przyjęcie (Teilnahme).

Dar apostolskości na poziomie sukcesji urzędu jest powicrzony hicrarchicznej wspólnocie. Przyjęcie go oznacza zadanie strzeżenia czystości wiary apostolskiej i troskę o nieprzerwane przekazywanie posługiwania apostolskicgo, aby nigdy nie budowano eklezjalnej wspólnoty w oderwaniu od fundamentu dwunastu Apostołów. Natomiast przyjęcie daru apostolskości na poziomie wyznawania wiary Apostołów oznacza zadanie dla wszystkich wiernych, każdego z osobna $i$ wszystkich razem. Podobnie przyjęcie pozostałych darów jest zadaniem wszystkich wiernych.

Dar powszechności domaga się od wszystkich misyjnego zaangażowania. Oznacza przychylność Boga dla wszystkich wyznawców Chrystusa, wczoraj, dziś i jutro (powszechność przeznaczenia) $\mathrm{i}$ obdarowanie ich pelnią laski i prawdy (powszechność uposażenia). Trzeba jednak tymi zbawczymi dobrami (łaską i prawdą) dzielić się, trzeba jc zanosić aż na krańce ziemi (por. Mt 28, 19n). I w tym sensie dar powszechnosci jest zadaniem.

Dar jedności, zakorzeniony na wieki w obecności jednego i tego samego Ducha we wszystkich wiernych, przygniotly bolesne podziały minionych wieków. Chwala i odwicczny zamysł Ojca, wola Chrystusa $(\mathrm{J} 17,21)$, rozwój dzieła ewangelizacji i misja Kościola, aby być sakramentem jedności dla całego rodzaju ludzkiego, domagają się jcgo ponownego odsłonięcia, przez pojednanie i życic w zgodzie (por. UUS 98). Dlatego też dążenie do zaprowadzenia widzialncj jedności powinno stanowić imperatyw każdego chrześcijańskiego sumienia.

Wreszcie dar świętości otrzymany przez wszczepienie w Chrystusa i oznaczający trwanie w Nim (świętość bytowa) potrzebuje ciągle oczyszczenia; przyzywa członków 
ludu Bożego do rozwijania swej świętości subiektywnej, czyli do postępowania zgodnego z formami moralinymi, ku pełni doskonatości Boga.

Mając to wszystko na uwadze eklezjologia communio podkreśla, że kobcielna wspólnota stanowi communio non plena. W'szyscy wierni powinni być swiadoni tego, że jest ciągle w drodze ku pełni Królestwie niebieskim i powinni się șiadomie angażować w jej dążenie ku pełnej powszechności (współudział w dziele ewangelizacji), dążenie ku pełnej jedności (współudział w dziele pojednania) i dążenie ku pełnej świętości (uspóludziat w dzjele uświęcania). W realizacji tych dążeń pasterze powinni swiadomie strzec apostolskiej tożsamości kócieinej wspólnoty.

Historia dowodzi, ze ludzkośc tej wspólnoty Kóscioła potrzebuje, za nią tęskni. Wystarczy wspomnieć czas rewolucji francuskiej. Gloszone wowczas hasta: wolnoḱt, rownost, braterstwo to zasady zycia chrześcijañskiej gminy, zawsze obowiązujące, niestety nicraz zaciemniane i sponiewierane w skutek moralncgo upadku ludzi Kościo1a. Budowanie wspólnoty opartej na tych zasadach jest budowanjem Kościola, ale tylko wowczas, gdy się pamięta o jej zakorzerieniu w Bogu, w Duchu Swiçtym. Nie wolno o tym zapominac w dobie budowania unii europejskiej i we wselkich staraniáuh o pokojowe wspótistnienie. Na przetomie tysiącleci ludzkość zdaje się mieć tylko takn alternatyong: Albo chrześcijańska communio jako laskawie udzielone, ponad wszelkie oczekiwania, spełnienie ludzkości, albo ewolucyjny konunizm obywający się bez Boga, który dąży do commumio jako urzeczywistnionego postępu w kierunku ulopijnego ubóstwicnia czlowieka ${ }^{\text {sh }}$.

W kontckşcie takiej altcrnatywy uybrzmiewa donioßle papieskie wolanje o krzewienie duchowosci komunist. Nie wystarczy określony program dzialań, Potrzeba odpowiednicj formacji i odpowiedzialnego życia każdego wiernego. Zanim prastapimy do programowania konkretnych predsiewzigt — pisze Jan Paweł II - nalezy krzwic duchowosc komumii, podkrestajgc jej znaczenie jako zasady wychowawczej wszedrie tam, gdzie fommia sie szafarze oltarza, duszpasterze i osoby konsekrowane, gdzie powricja rod iny i wspotnoty (NMI 43). Chodzi o duchowość, którą znamionuje osobowe otwarcie na Boga i na to, co daje, cryli o postawę zawierzenia Bogu, kortemplacji Bogá. Stanowi ona podstawę komunii czlowieka z Bogiem i niesie wielką szansę obudzenia ì ozywienia braterstwa wszystkich wiernych, ich otwartości na swiat oraz ich wspólpracy z ludómi dobrej woli. Bez tych postaw trudno tak urzeczywistniać Kościót, aby byt domem dla swych dzieci i szkolą jednosci dla swiata.

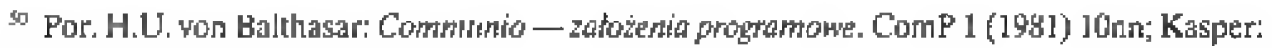
Kofriot jako wrghthota, dz. cyt, s 28 .

H. Nad iston i elementami tej duchowosci zastanawiali sie modzi teologowit, z wielu krajowyeh ofrodkifw tcologicznych, w ramach XXXIV Tygodnia Eklezjologicznego na Katolickim Uniwersytecie Lubelskin. Zorganizowalo go studenckie Kolo Naukowe Teologow KUL w dniach 11-15 març 2002 roku pod hastem, "Cyric Kosciot domem ì szkold komunili". 